\title{
Abortion activism, legal change, and taking feminist law work seriously
}

MÁIRÉAD ENRIGHT

KATHRYN MCNEILLY

FIONA DE LONDRAS*

\begin{abstract}
Abortion laws in the Republic of Ireland and Northern Ireland have recently undergone radical reform. This occurred following a 2018 referendum in the Republic and the passing of the Northern Ireland (Executive Formation etc) Act 2019 in Northern Ireland. In both jurisdictions, these legal changes are the products not only of moments of constitutional and legislative action or of litigation, but of decades of feminist protest and strategising that both generated and exploited moments of legal opportunity. In this article, drawing on a 2018 workshop and qualitative interviews with feminist activists, we focus attention on what we call the 'feminist law work' involved in reform, highlighting the role of non-lawyer activists in achieving legal change in instrumental, creative, emotional, and laborious ways. We argue that 'feminist law work' should be taken seriously as a bighly skilled and indispensable driving force in formal legal change processes.
\end{abstract}

Keywords: abortion; activism; law reform; legal change; feminist law work; feminist legal studies; Ireland; Northern Ireland

Interviewer: If I had to ask you, right now, what's going on - what are you doing to change the law [on abortion], what would your answer be?

Kellie O'Dowd (activist, Alliance for Choice): What are we not doing?

$\mathrm{O}$ ver the last two years, the law on access to abortion has changed substantially in both jurisdictions on the island of Ireland. In the Republic of Ireland, the 8th Amendment to the Constitution was repealed and replaced with a constitutional provision permitting the Oireachtas to regulate the termination of pregnancy, which was achieved with the Health (Regulation of Termination of Pregnancy) Act 2018. In Northern Ireland, abortion was

* Reader in Feminist Legal Studies, Birmingham Law School; Senior Lecturer, Queen's University of Belfast School of Law; Professor of Global Legal Studies, Birmingham Law School.

This research was supported by research activity grants from Birmingham Law School and Ulster University School of Law, a research activity grant from the SLSA to support interview transcription (Enright), and the Philip Leverhulme Prize (de Londras, PLP-2017-181). We are grateful to Dr Catherine O'Rourke of the Transitional Justice Institute, University of Ulster, for co-organising the workshop and securing funding to support it, as well as for her discussions on the animating ideas of the paper. Our thanks also to all of our interviewees, and to everyone who attended the workshop, for their time and their feminist law work. 
decriminalised in 2019, ${ }^{1}$ and is now legally available pursuant to new regulations introduced in $2020 .^{2}$ In both cases, the changes were brought about by particular legal 'events' constitutional referendum, legislative change, the passage of regulations - but those events were preceded by decades of feminist activism and agitation, ${ }^{3}$ including substantial amounts of what we term 'feminist law work'. ${ }^{4}$ This is work that takes place alongside, and sometimes against, more formalised law work and activity undertaken by voluntary and non-governmental organisations. It is apposite, now, to reflect on the dynamics of legal change in abortion law reform in Ireland and, particularly, to attend to and recognise the role that feminist law work has played in bringing that change about.

As explained further below, the term 'feminist law work' is intended to capture the manifold ways in which non-lawyer feminist activists engage with law, legal mobilisation, legal consciousness, legal institutions and legal argumentation in order to try to achieve their desired end of safe, legal, and local abortion for pregnant people who seek it. Our aim in this paper is not to provide a comprehensive account of the decades of feminist law work that was undertaken in Ireland or, indeed, to suggest that formal legal changes have brought that feminist law work to an end. Instead, using structured conversations with eight invited abortion rights activists from Ireland and Northern Ireland as our jumping-off point, we seek to contribute to the complex retelling of the stories of abortion law reform in Ireland and Northern Ireland.

The paper proceeds in five main parts. First, we outline our ethical and methodological approach (Part 1), before briefly describing the prevailing legal and political context in which the feminist law work that our participants discuss took place (Part 2). We then look in some detail at three different elements of feminist law work that emerged especially clearly in our engagement with activists and which shaped our understanding of the phenomenon: ambivalence about law (Part 3), the multifaceted nature of feminist law work (Part 4), and feminist law work's 'everydayness' (Part 5).

\section{Our ethical and methodological approach}

In this article we investigate the feminist law work undertaken by eight non-lawyer activists whom we invited to a workshop held in Ulster University, Belfast, on 23 November 2018. The participants were engaged in different ways in abortion rights activism, with three working primarily in the Republic of Ireland and five in Northern Ireland. Our workshop took place at a crucial turning point: Irish abortion law had been liberalised and there was a strong sense (as the slogan went at the time) that 'the North is Next'. ${ }^{5}$ Northern Irish feminist activists were at this point concentrating their attention on lobbying for abortion law reform at Westminster. Before the workshop, and in preparation for the discussion to be held there, Enright interviewed a number of the participants. These pre-workshop interviews helped us to shape the workshop discussion, which was oriented towards identifying how the activists to whom we spoke thought

1 Northern Ireland (Executive Formation etc) Act 2019.

2 Abortion (Northern Ireland) Regulations 2020.

3 Fiona Bloomer, 'Protests, parades and marches: activism and extending abortion legislation to Northern Ireland' in Lisa Fitzpatrick (ed), Performing Feminisms in Contemporary Ireland (Carysfort Press 2013) 245-266; Ruth Fletcher, 'Silences: Irish women and abortion' (1995) 50(1) Feminist Review 44.

4 See e.g. Sally Sheldon, Jane O’Neill, Clare Parker and Gayle Davis, “Too much, too indigestible, too fast?” The decades of struggle for abortion law reform in Northern Ireland' (2020) 83(4) Modern Law Review 761.

5 Melissa Davey, “North is next”: fresh fight for grassroots power that beat Ireland abortion ban' The Guardian (London, 1 June 2018) <https://www.theguardian.com/world/2018/jun/02/north-is-next-freshfight-for-grassroots-power-that-beat-ireland-abortion-ban $>$. 
about and enacted their relationship with law. The concept of feminist law work emerged from the workshop, rather than driving it. As we discussed what these women had spoken about, how they thought about law, and how they had trained themselves to challenge, manipulate, shape, undermine, ridicule and reform law as part of their activism, it became clear to us that what they had described was a vital form of legal labour rooted in feminist commitments and playing itself out in their everyday engagements with law, politics, reproduction, (il)legality, and activist strategising. Ethical approval for this qualitative research was granted by the University of Birmingham. All workshop participants and interviewees gave full informed consent to their participation in the research as well as use of the resulting data in published outputs. All participants reviewed a draft of this article prior to final publication.

The participants in our workshop and interviews were women who have been active in struggles to reform abortion law in Northern Ireland and the Republic of Ireland, and in the spaces between them. Ailbhe Smyth has been involved in feminist and reproductive rights activism for more than 40 years, is head of the Coalition to Repeal the 8th Amendment, and was one of the co-directors of Together for Yes, the official civil society platform for a 'Yes' vote in the May 2018 referendum. Linda Kavanagh is a longtime leader within the Abortion Rights Campaign and worked in social media for Together for Yes. Erin D'Arcy is an artist and founder of 'In Her Shoes'; an intervention in the referendum campaign which curated women's anonymous first-hand stories of being denied abortion care in Ireland. She published these stories on Facebook and, near the end of the campaign, in a hard copy form for distribution during canvassing. Of the Northern Ireland workshop participants, Sarah Ewart is a litigant who has undertaken legal action to challenge Northern Ireland's abortion law. ${ }^{6}$ Her mother Jane Christie, who also contributed to the conversation, accompanied her. Emma Campbell and Kellie O'Dowd were then co-directors of Alliance for Choice. Goretti Horgan is an activist with Alliance for Choice in Derry, work which she undertakes alongside her role as an academic at Ulster University working on abortion research.

Our aim in bringing these eight interlocutors together was not to 'tell the whole story' of abortion law reform 'North and South'; rather it was to begin a conversation on feminist activists as key actors in processes of legal change, complementing existing literature on 'formal' law reform in both jurisdictions. ${ }^{7}$ We acknowledge that if eight different women had been in the room with us, or if the same eight women had been in the room with us six months earlier or later, the event could have been very different. We are conscious too that our participants did not include people working specifically to agitate for reproductive autonomy and freedom for women of colour, migrant women, women with disabilities, Traveller women, transpeople, and other specifically impacted persons who may seek abortion care. Those activists' experiences of law reform will have been different, and their experience of, engagement with, and perhaps rejection of feminist law work and its inevitable pragmatism is worthy of separate exploration. For the

6 Ewart's (Sarah Jane) Application [2019] NIQB 88.

7 For example, Joanna Erdman, 'Procedural abortion rights: Ireland and the European Court of Human Rights' (2014) 22(44) Reproductive Health Matters 22; Máiréad Enright et al, 'Abortion law reform in Ireland: a model for change' (2015) 5(1) feminists@law

<https://journals.kent.ac.uk/index.php/feministsatlaw/article/view/173>; Fiona de Londras, 'Fatal foetal abnormality, Irish Constitutional law, and Mellet v Ireland (2016) 24(4) Medical Law Review 591; Fiona Bloomer and Eileen Fegan, 'Critiquing recent abortion law and policy in Northern Ireland' (2013) 34(1) Critical Social Policy 109; Fiona Bloomer and Kellie O’Dowd, 'Restricted access to abortion in the Republic of Ireland and Northern Ireland: exploring abortion tourism and barriers to legal reform' (2014) 16(4) Culture, Health and Sexuality 366. 
purposes of this starting conversation, however, these were the eight activists with whom we engaged, and whose experiences animate our account.

In Northern Ireland, Alliance for Choice is the leading grassroots voice on abortion law reform. In addition to providing direct practical support to women who need abortions, it engages with other advocacy groups, such as Amnesty International, the Northern Ireland Human Rights Commission, and the London Irish Abortion Rights Campaign. In Ireland, particularly in the lead-up to the referendum vote, a much larger collective action campaign came together which included a wide range of loosely connected groups and individuals; some single issue, and others more established. Groups such as the Coalition to Repeal the 8th Amendment were key to persuading organisations which do not have a primary focus on reproductive rights issues, such as trade unions, to enter the fray on behalf of the movement. During the formal referendum campaign, three organisations - the Abortion Rights Campaign, the Coalition to Repeal the 8th Amendment and the National Women's Council of Ireland - came together to form an official civil society campaign for a 'Yes' vote, called Together for Yes. ${ }^{8}$ Most, although not all, pro-choice organisations in Ireland were affiliated with Together for Yes during the referendum campaign. In spite of these differences, the movements in both jurisdictions are interlinked and, in some instances, interdependent, and they have often worked together. Women from the North, and particularly from Alliance for Choice, campaigned actively for the 'Yes' vote in the Republic's referendum, especially in the border counties. Similarly, since the Amendment was repealed, some activists in the South have been involved in work to facilitate access to abortion services for women from Northern Ireland. Activists are conscious that women who live in one jurisdiction may, in future, need to access services in the other. For these reasons, it is productive to consider all of these activists together.

By use of the term 'activist', we mean social change agents who participate in some form in a social movement/collective action. ${ }^{9}$ Self-identifying as an activist is not essential to this definition, ${ }^{10}$ and indeed some of our participants did not overtly embrace this label. Our engagement with feminist activists in the latter stages of reform struggles on both parts of the island makes clear the importance to law and lawyers of recognising how these activists' actions in, with, to and against law helped to shape reform processes. In engaging with our activist participants, we were not aiming to arrive at 'the truth' of feminist activist engagement in law in the abortion rights movements in Ireland and Northern Ireland; any attempt to do so would be as distorting ${ }^{11}$ as attempts to create dominant narratives of abortion law reform that underplay or even invisibilise feminist, activist labour. Neither do we attempt to narrate the internal dynamics of these groups

8 For official accounts of Together for Yes's strategy and activities, see Michael Barron, Learning from the 2018 Together for Yes Campaign (2019)

<https://www.togetherforyes.ie/app/uploads/2019/11/2019_TFY_Review.pdf?fbclid=IwAR33cJUSgdHAUFCqbh3Qh01oCLk8Sk0s2EqHanZj2e7VejHiV0SfEJ_k3U>

9 Chris Bobel, 'I'm not an activist, though I've done a lot of it': Doing activism, being activist and the 'perfect standard' in a contemporary movement' (2007) 6(2) Social Movement Studies 148. For wider discussion, see Leila Rupp and Verta Taylor, 'Forging feminist identity in an international movement: a collective identity approach to social movements' (1999) 24(2) Signs 363; Jennifer Baumgardner and Amy Richards, Manifesta: Young Women, Feminism, and the Future (Farrar, Strauss \& Giroux 2000); Scott Hunt and Robert Benford, 'Collective identity, solidarity and commitment' in David Snow, Sarah Anne Soule and Hanspeter Kriesi (eds), The Blackwell Companion to Social Movements (Blackwell 2004).

10 Bobel ibid 157.

11 See generally Antoinette Burden, "History" is now: feminist theory and the production of historical feminisms' (1992) 1(1) Women’s History Review 25. 


\section{Abortion activism, legal change, and taking feminist law work seriously OA11}

or the many other feminist groups engaged both recently and earlier in the reproductive rights struggles in Ireland. We recognise that there is no singular truth of these engagements, or one story of reform; rather there are multiple stories and narratives that together form the complex, textured background to the reform of the law in both jurisdictions. However, there is a 'past' to which multiple actors increasingly seek to lay claim; notably, in the South, some political parties seek to represent repeal of the 8th Amendment as a product of their actions or of a 'quiet revolution', 12 seemingly erasing the substantial feminist law work that underpinned it. Informed by the intellectual commitments of feminist historiography, ${ }^{13}$ we know that recognising the authority of feminist activists' narrative accounts is part of creating the legal history of abortion law reform in Ireland. ${ }^{14}$ As Cheryl Glenn has written in another context, 'in choosing what to show, how to represent it, and whom to spotlight ... [we] subtly shape our perceptions' 15 of the past. In this paper, we choose to show, represent, and spotlight feminist law work and the activism that underpins it. Concentrating on these narratives makes clear the importance of rejecting any simplistic 'legal' telling of abortion law reform in Ireland and Northern Ireland in which court cases, legislative reform, or parliamentary debates are presented as isolated and self-generated incidences of legal and political engagement.

Although it is not an oral history or biographical project, our ethical and methodological approach to the material offered to us by the participants is informed by a commitment to pluralising the historiographical record(s) of significant events, and to the 'ethically and intellectual responsible gesture that disrupts ... frozen memories in order to address silences, challenge absences, and assert women's contributions to public life'. ${ }^{16}$ As such we do not fact-check or authenticate the accounts and recollections of our participants; nor is any such process necessary. Instead, we recognise personal recollection and experience as a valid source of understanding processes of legal change and see the collection of such accounts and their analysis as a means of understanding narrated memories to which law and lawyers are generally insufficiently attentive. In this, we are informed and influenced by feminist commitments to recognising the authenticity of first-person narrative, the epistemological value of personal experience, and the standing of activists as the most qualified narrators of their own participation in activist endeavours. ${ }^{17}$ Thus, while we contextualise the workshop and the moment in time in which we spoke to these feminist law workers in Part 2, we do not otherwise seek to explain, validate, or somehow 'authenticate' participants' accounts. Instead, we recognise them as the experts in their own experiences of feminist law work.

We use the word 'work' for a reason. This paper talks about a range of legal activities which formed part of everyday abortion rights activism; peer and public legal education,

12 Following the result of the referendum to repeal the 8th Amendment, Taoiseach Leo Varadkar claimed that 'a quiet revolution has taken place'. See, for example, RTE News, 'Result is culmination of quiet revolution, says Varadkar’ 26 May 2018 <https://www.rte.ie/news/eighth-amendment/2018/0526/966132-reaction/>.

13 Following Chandler, we understand historiography as 'a critical consciousness at work in the writing of history': James Chandler, England in 1819: The Politics of Literary Culture and the Case of Romantic Historicism (University of Chicago Press 1998) 77.

14 As Enoch and Bessette write, 'Feminist recovery ... depends on the archive.' Jessica Enoch and Jena Bessette, 'Meaningful engagements: feminist historiography and the digital humanities' (2013) 64(4) College Composition and Communication 634, 637.

15 Cheryl Glenn, 'Lies, and method: revisiting feminist historiography' (2000) 62(3) College English 387, 388.

16 Ibid 389.

17 See generally the contributions to Sandra D Harding (ed), The Feminist Standpoint Theory Reader: Intellectual and Political Controversies (Routledge 2004). 
developing new legal skills, lobbying institutional legal actors, mobilising popular support for concrete legal change, generating narratives to delegitimate existing law and justify reform, organised law-breaking, supporting litigation and more. These projects were multifaceted: activists were doing many things at once, often across many different institutional, political and community environments, and recognising that different dispositions towards law are required and appropriate in different settings. They might be drafting legislative amendments in one environment and distributing 'illegal' (but safe) abortion medication in another. These activities were often unpaid, considered unprofessional or illegitimate, done 'on the move', or in private or domestic space. In characterising these activities as 'work', we draw on a long feminist tradition of bending and stretching the concept of work in order to honour women's marginalised labour. ${ }^{18}$ We not only recognise activists' collective and individual engagement with law as work, but demonstrate that aspects of mainstream law reform work are dependent on feminist law work At the same time, we recognise that feminist law work is alienated labour ${ }^{19}-$ it is not only a site of value and meaning-making. It can also be difficult and disappointing. As we see in this paper, feminist law work does not indicate a legal vocation, or an unambivalent commitment to law. It often looks more like reluctant, resistant or pragmatic engagement.

Our attention to feminist law work on the island of Ireland has relevance beyond these jurisdictions. What this micro-story reveals is that feminist engagement with law, even if 'cheeky'20 and irreverent, can be productive and heterodox, challenging conventional or dominant tropes about legal (im)possibility, and that activists engaging as feminist law workers consciously reclaim law from 'elite' disciplinary or professional 'ownership' by developing skills and knowledge that allow them to trouble, and force change within, orthodox legal thinking. Thus, while presenting a 'snapshot' of the abortion law reform processes in Ireland and Northern Ireland, this paper also identifies and insists upon the importance of a frame for engagement - this feminist law work that is discernible in reproductive rights activism all over the world, as well as in other social justice campaigns in which feminist activism is at the forefront.

\section{Contextualising abortion activism in Northern Ireland and Ireland}

As already noted, abortion laws in the Republic of Ireland and Northern Ireland have recently seen legal transformations unimaginable even a decade ago. In Northern Ireland, abortion was previously criminalised under sections 58 and 59 of the Offences Against the Person Act 1861 with very few exceptions. In October 2019, abortion was decriminalised in the jurisdiction by the Northern Ireland (Executive Formation etc) Act 2019. This was legislative action taken by Parliament at Westminster during a period where the devolved Assembly at Stormont was not functioning. Regulations pertaining to legal provision of abortion were introduced in March 2020. In the Republic, the

18 See further, Kathi Weeks, The Problem with Work (Duke University Press 2011); Silvia Federici, Revolution at Point Zero (PM Press 2012); J K Gibson-Graham, A Postcapitalist Politics (University of Minnesota Press 2006).

19 Alison Jaggar, Feminist Politics and Human Nature (Rowman \& Littlefield 1983) 307

20 In this we are influenced by Fletcher's articulation of 'cheeky witnessing' which she claims has three elements: 'First, it is messy and irreverent in innovating with names to display the mixed genealogies of sources of feminist knowledge. Second, cheeky witnessing generates novel subject-figures, such as migrant cleaners, who make knowing connections between different reproductive labourers as observers of the trail in diaspora space. Third, cheeky witnessing places funny objects, knickers in this instance, so as to join up particular public locations and make them more, if unevenly, comfortable for sexual and reproductive bodies.' Ruth Fletcher, 'Cheeky witnessing' (2020) 124 Feminist Review 124. 


\section{Abortion activism, legal change, and taking feminist law work seriously OA13}

constitutional provision which prohibited almost all abortions - Article 40.3.3, known as the 8th Amendment - was repealed in May 2018. New abortion legislation, the Health (Regulation of Termination of Pregnancy) Act 2018, was passed some months later and, in principle, abortion care is now legally available across the country.

This change was a long time coming. Neither jurisdiction embraced liberalising action to reform the law on abortion for several years. ${ }^{21}$ Institutional dynamics within each jurisdiction mean that change to the law took different forms. In Northern Ireland, for example, a referendum was unnecessary since legal change was largely in the hands of elected representatives. Targeted strategic litigation has recently been employed in domestic courts to some positive effect. ${ }^{22}$ The relative institutional autonomy of Westminster and the devolved Assembly at Stormont facilitates change to abortion law by the ordinary mechanisms of legislative reform, should elected representatives be moved to use them. ${ }^{23}$ This situation was, however, complicated by the collapse of the Stormont Assembly between January 2017 and January 2020, and it was eventually Westminster legislation that facilitated decriminalisation. In the Republic, by contrast, the 8th Amendment and an unreceptive judiciary were perceived to present an impenetrable obstacle to successful litigation. Strategic cases and petitions were brought in international spaces instead. A referendum was not only unavoidable but perceived as a beneficial way to break legislative deadlock.

There are thus important differences in experiences across the jurisdictions. However, there are also inevitable commonalities and connections. First, both jurisdictions have had definitively non-linear experiences of the road to reform of abortion law. In these nonlinear processes, no one event in either jurisdiction was responsible for triggering reform. Rather, legal change followed the culmination of multiple events particular to each jurisdiction. Contingent, and often unexpected, moments have been opportunities to develop and publicise reform work. In the Republic, these moments include the death of Savita Halappanavar in 2012 and the experiences of Amanda Mellet and Siobhan Whelan in 2010 and 2011 who were required to travel to access abortion services in cases of fatal foetal abnormality. In Northern Ireland, Sarah Ewart's sharing of her experience of fatal foetal abnormality in 2013, a judicial review by the Northern Ireland Human Rights Commission initiated in $2015,{ }^{24}$ and an Inquiry by the United Nations Committee on the Elimination of All Forms of Discrimination Against Women (CEDAW) which reported in $2018^{25}$ are all notable examples. Second, legal change is only the starting point for wider processes of transition in Ireland and Northern Ireland. The new abortion laws are still being embedded and reconfigured in both parts of the island. Details around practical provision and application of the law remain to be settled. In this respect, reform was not the end of the story. At the time of our interviews and workshop activists were still working on influencing the practical details and roll-out of the new legislation on the

21 Siobhan Mullally, 'Debating reproductive rights in Ireland' (2005) 27(1) Human Rights Quarterly 78; Goretti Horgan, 'Abortion and citizenship rights in a devolved region of the UK' (2014) 13(1) Social Policy and Society 39; Lisa Smyth, Abortion and Nation: The Politics of Reproduction in Contemporary Ireland (Routledge 2017); Sheldon et al (n 4).

22 Family Planning Association for Northern Ireland v Minister for Health, Social Services and Public Safety (SPUC NI and others intervening) [2004] NICA 39; The Northern Ireland Human Rights Commission's Application [2015] NIQB 102.

23 Jennifer Thomson, Abortion Law and Political Institutions: Explaining Policy Resistance (Palgrave 2019).

24 Northern Ireland Human Rights Commission (n 22).

25 CEDAW Committee, Report of the Inquiry Concerning the United Kingdom of Great Britain and Northern Ireland under Article 8 of the Optional Protocol to the Convention on the Elimination of All Forms of Discrimination Against Women (2018) UN Doc CEDAW/C/OP8/GBR/1. 
ground. Third, feminist activists North and South of the border were motivated to speak back to the effects of law on the lived experiences of gendered subjects and troubling restrictive and heteronormative legal frameworks. ${ }^{26}$ They were concerned with the empowerment of women and pregnant persons, attentive to long-term, structural gender imbalances within their respective jurisdictions and affected by first-hand experience of the effects of the law on the ground. We will now turn to explore the work they undertake in more detail.

\section{Ambivalence about law in feminist law work}

Despite law's obvious uses - its symbolic weight ${ }^{27}$ and its connection to coercive power that can be used to redistribute rights and resources - feminist organising has always had an ambivalent relationship with law; feminists cannot help but be conscious of law's violence. ${ }^{28}$ There are recognised dangers; that a movement will invest too many of its resources in legal change and, in the process, become complicit with darker aspects of legal power. ${ }^{29}$ Law tends to subject women to ever more extensive legal control, even in the guise of liberalisation, and can impose its logic on wider political discourse in ways that suppress women's desires and experiences. ${ }^{30}$ In discussions with our participants, it became clear that, while they engaged closely with law and its various spaces, they maintained a similar feminist suspicion of law. This was evident in how they understood the function of law in their activist campaigns for change. The activists in our conversation were clear that they undertook efforts towards reform because they knew, as Emma Campbell noted when we spoke with her, that the prevailing law harmed women and saw advocating for legal change as an essential 'harm reduction exercise'. They were not, however, comfortable with law. In part, this was because law's insiders are not always comfortable with them, or with their place as agitators for law reform. Goretti Horgan brings up this issue in the context of the relationship between feminist protest and litigation:

So, we always had this kind of thing where we were talking about legality even as we were street campaigning, you know? We never saw the two as being separate. I think that is until the Family Planning Association case. ${ }^{31}$ And then we [activists] were told that we shouldn't do any campaigning until the case was out of the way, until the case was heard and ruled on. Because you know, were we to be on the streets or we were told we shouldn't be outside of the court, you know, we shouldn't be doing any campaigning really, you know just let the courts handle it. Now, obviously we didn't take any notice of that. But there was, like an imperative for a while there where you know, where we were frowned upon, where we were seen as being kind of wreckers.

26 For an overview of how feminist legal scholars have described and approached these types of frameworks, see Katharine Bartlett (ed), Feminist Legal Theory: Readings in Law and Gender 2nd edn (Routledge 2018); Janet Halley, Prabha Kotiswaran, Rachel Rebouché and Hila Shamir (eds), Governance Feminism: Notes from the Field (University of Minnesota Press 2019).

27 Sally Engle Merry, 'What is legal culture? An anthropological perspective' (2010) 48(2) Journal of Comparative Law 40.

28 Austin Sarat and Thomas Kearns (eds), Law's Violence (University of Michigan Press 1993); Rosemary Hunter, 'Law's (masculine) violence: reshaping jurisprudence' (2006) 17 Law and Critique 27; Hilary Charlesworth, 'Feminist ambivalence about international law' (2005) 11 International Legal Theory 1.

29 See, for example, Ratna Kapur, 'Human rights in the 21 st century: take a walk on the dark side' (2006) 28(4) Sydney Law Review 665.

30 Nivedita Menon, Recovering Subversion: Feminist Politics beyond Law (University of Illinois Press 2004) 5.

31 Family Planning Association (n 22). For discussion see Ruth Fletcher, 'Abortion needs or abortion rights? Claiming state accountability for women’s reproductive welfare’ (2004) 13(1) Feminist Legal Studies 123. 


\section{Abortion activism, legal change, and taking feminist law work seriously OA15}

In their ambivalence towards law, feminist activists refuse law's respectability, decentre law in their work and campaigns, and often engage in a creative and provocative play around law. Let us explore each of these in turn.

\subsection{REFUSING LAW'S RESPECTABILITY}

At a fundamental level, feminist activists refuse the respectability of law and the formal legal domain. In other words, they question its authority and proprietary place in social life. Of course, that respectability is complicated. In the Northern Irish context, more broadly, activists are conscious of an older history of law's role in legitimating or not effectively counter-acting violence. ${ }^{32}$ Emma Campbell summarised:

And, you know, growing up in Northern Ireland, the law was always very much used as a tool of control to the people as far I understood it, you know. We had, you know, we grew up having to go through army turnstiles to get into the town centre every day, that's how we, how I feel that I saw the expression of the law in a, I don't know, embodied in a human form. So, I don't give a shit about the law, really [laughs].

This lack of automatic respect for law has played out in more recent pro-choice organising in both jurisdictions. While law's failings encouraged feminist activists to engage in feminist law work towards reform, these same failings meant that law was marginalised when activists imagined their desired outcomes. For example, feminist organisations such as Alliance for Choice and the Coalition to Repeal the 8th Amendment did not, in principle, favour the creation of new legislation to regulate abortion access. They preferred the approach of jurisdictions such as Canada and Cuba where regulation is the role of the healthcare, as opposed to the legal or criminal justice, system. ${ }^{33}$ For these groups, the preference was repeal of the existing law, followed by decriminalisation and limited legal regulation. As Ailbhe Smyth put it, 'none of the pro-choice organisations really wanted there to be legislation'. However, this preference was gradually tempered by an understanding that law - and feminist engagement with it - was necessary in the given circumstances.

In the Irish context, there seemed to be an understanding that moving from hyperrestrictive constitutional regulation to 'no' statutory regulation of abortion would not garner sufficient support, at least in political institutions, so that during the referendum pro-choice organisations endorsed the government's proposed legislative scheme, albeit at times with some reservations. For Linda Kavanagh, the sense of law's symbolic and communal role was also crucial:

To be honest ... the legality of abortion isn't necessarily that important to your grassroots anarchist leftie activist. But in the wider sense, we know that people love the law. They think that morality lies within the law or some of their morality comes from the law, which to me is really bizarre but is true. So that when you decriminalise something, you do remove some of the stigma and shame. And so, kind of being aware of that. So, that's kind of where respectability comes in there.

32 See, for example, Fionnuala Ní Aoláin, The Politics of Force: Conflict Management and State Violence in Northern Ireland (Blackstaff Press 2000); Fionnuala Ní Aoláin and Michael Hamilton, 'Gender and the rule of law in transitional societies' (2009) 18(1) Minnesota Journal of International Law 380; Monica McWilliams, 'Violence against women and political conflict: the Northern Ireland experience' (1997) 8 Critical Criminology 78.

33 Rachael Johnstone, After Morgentaler: The Politics of Abortion in Canada (University of British Columbia Press 2017); Carrie Hamilton, Sexual Revolutions in Cuba: Passion, Politics, and Memory (University of North Carolina Press 2017). 
This account of the emergence of an unsettled, if strategically coherent, attitude to law and its respectability is not surprising. Patricia Ewick and Susan Silbey argue that legal consciousness is 'multiple and contingent'; simultaneously obedient and resistant. ${ }^{34}$ In the same situation, individuals may maintain a sense of themselves as 'before', 'with' and 'against' the law. It is not surprising then that participants in our workshop maintained a strong critical oppositional sense of law's dualities and were reluctant to embrace legal change as an end in itself, even as they engaged law sometimes for their own purposes. ${ }^{35}$ In feminist law work, this refusal of law as something respectable and deserving of deference is accompanied by a decentring of law.

\subsection{DeCentring LaW}

Carol Smart famously encouraged feminists to decentre law and prefer other strategies for change in order to avoid legal colonisation of feminist campaigning. ${ }^{36}$ This was echoed in our participants' clear sense that legal change was not sufficient to deliver meaningful reproductive justice. Irish and Northern Irish feminists are under no illusion that law offers an easy solution to the problems they are grappling with. A reluctance to engage with law as an end in itself appears to stem from participants' concrete experience of legal frameworks that have either withheld help from or failed appropriately to respond to the real-life needs of women and pregnant persons. This reluctance does not dissipate even when some of the key demands and desired outcomes of feminist law work have been achieved, such as repeal of the 8th Amendment. The long delay between the referendum date (25 May 2018) and the coming into force of the legislation that made provision for lawful abortion (1 January 2019) - the time during which our workshop took place - was a temporal site of real frustration with the law. Erin D'Arcy reflected on this, saying:

I just received [an online message] last night ... it's been six months since we had the vote and .... she's having to email [the 'In Her Shoes' Facebook page] anonymously instead of just going to her GP.

In some ways, these disappointments are anticipated from the beginning of feminist law reform campaigns. As Kellie O’Dowd said of Alliance for Choice, 'we realised very early on in our campaign that legislative change is never going to be enough'. This insight was not only a product of experience in abortion rights activism but a conclusion drawn from feminist law work in other areas. ${ }^{37}$ For her, campaigns to achieve equal pay in the $1970 \mathrm{~s}$ in particular revealed that formal law reform is often limited in what it can achieve and must be supplemented with meaningful change in socio-political attitudes and culture. Legal struggle is intertwined with social struggle, and feminist demands extend beyond anything law alone could provide. ${ }^{38}$ This understanding leads legislative reform to be one, but not the only, focus of the work Alliance for Choice does. As O’Dowd put it:

34 Patricia Ewick and Susan Silbey, The Common Place of Law: Stories from Everyday Life (University of Chicago Press 1998).

35 Michael McCann, Rights at Work: Pay Equality and the Politics of Legal Mobilization (University of Chicago Press 1994) 233.

36 Carol Smart, Feminism and the Power of Law (Routledge 1989).

37 For discussion, see Reg Graycar and Jenny Morgan, 'Law reform: what's in it for women?’ (2005) 23(2) Windsor Yearbook of Access to Justice 393; Susan Armstrong, 'Is feminist law reform flawed? Abstentionists and sceptics' (2004) 20(1) Australian Feminist Law Journal 43.

38 Boaventura De Sousa Santos, 'The World Social Forum and the global left' (2008) 36(2) Politics and Society 247. 


\section{Abortion activism, legal change, and taking feminist law work seriously OA17}

... along with campaigning and lobbying around legislative change, we need to change the hearts and minds of people ... we bring a very grassroots and personal experience to law reform but we don't put all our eggs in one basket.

Similarly, Linda Kavanagh remembers that the stakes the Irish referendum were far broader than constitutional change:

And I suppose, no, I don't feel like I was just advocating for constitutional reform, and very few people that I would ever deal with would be in it simply for the constitutional reform aspect. It was that we knew we needed to make this change. We knew it was ... For me and for the organisation that I volunteer with, it's that we knew this was the next obstacle and we weren't going to get anything unless this was removed ... But I think not a lot of people would just be in it for the sheer joy of change of the constitution.

Awareness of this relationship between law and social change does not necessarily lead to the same strategic conclusions. For Kellie O'Dowd, awareness of the limitations of the incrementalist approach to legislation then about to be passed in the Republic only strengthened the need to ensure that the Alliance continued to ask for the broadest and most comprehensive possible legislative provision in the North. By contrast, for Ailbhe Smyth, in heading a coalition whose members differed widely on the proper legal approach to abortion, and in the absence of a legislative proposal that all were agreed on, acknowledging law's limitations meant adopting a narrow legal project. She explained that legal change takes place in stages, and her role, as she saw it, was necessarily confined to getting the initial vote in favour of repeal of the 8th Amendment, before returning the legislative question to the parliament.

I saw my job in the Coalition as repealing the Eighth Amendment - actually, we did that, and that had to be done ... I don't think any of us ever thought ... or most of us didn't think that the legislation we would get straight up after repeal would be perfect, and indeed it is obviously very, very far from perfect ... I'm not the expert on this aspect of things. So I'll quite happily say, not that it's altogether in other people's hands, because we all have a vested interest but that the legislative part is really in your [ie lawyers'] hands now, more than in the hands of activists like me.

Although they were aware of law's limitations, this group of activists was also conscious of its power. Although law was not venerated, it could be used instrumentally to try to compel action by otherwise-unresponsive states. They could deploy law as 'a stick to beat the establishment with' (Linda Kavanagh). They recognised the formal, establishment power of the law to compel the state. At the same time, this recognition was tinged with irreverence for law and for state power. As Linda Kavanagh put it, engagement with law is such an effective tool of persuasion for the establishment because, 'you know ... they are horny for the law. They love it.' For Alliance for Choice, refusal to venerate law was bound up with a willingness to get around it, ridicule it, break it, or subvert it as necessary to ensure abortion access for the women they wanted to support. Emma Campbell noted:

... as an activist organisation we've been happy not to take the law that seriously on many occasions ... the law is an ass so we'll do whatever we can around, above and beyond it, whenever we can.

\subsection{TICKLING LAW}

Precisely because it does not take its law 'that seriously', Alliance for Choice has been able, thirdly, to emphasise creativity in their approach to law reform. It is less persuaded by law's existing limits and boundaries than by the need to respond to problems on the 
ground. This has led feminist activists to be more interested in innovatively combining international approaches than establishment lawyers might be. Emma Campbell explains:

I am a] creative problem solver because I come from, you know, a creative background. And I get a little bit frustrated when legal people, let's say, or political people use or describe or imagine what the future looks like but only looking at their small tiny bit of experience or example of what they already have in front of them. Because, you know, especially from being at international conferences and you see the brilliant way that some countries have dealt with the fact that they have restrictive laws but they have interpreted, for instance, they have interpreted the word 'health' to include the World Health Organisation interpretation of that which is, which includes social issues, which includes mental health, which includes being able to provide for your family. So ... on a day to day basis we get people phoning asking us how we can help them. And so as people who have been at the, I guess the sharp end of physically providing abortion help or providing abortions or physically being the body in between a protestor and a person, then your approach is probably a little bit more pragmatic and a little bit less ... [W] feel frustrated that they so almost pedantically interpret the law, interpret the law conservatively and don't see any wiggle room in there where others might ... you know, there are definitely lawyers in other countries and in other contexts that have the same law in front of them and see it differently, you know.

Emma describes Alliance for Choice's feminist law work as 'tickling law'; that is, deploying agentic resources to go beyond a docile and disciplinary relation to law in order to engage in play and provocation around law and its limits. ${ }^{39}$ In this respect, feminist law work often employs significant creativity, playing games with law and pushing its boundaries in ways that transcend law's control. ${ }^{40}$ This is designed to test law, to reveal its hidden limits, effects or hypocrisies and, ultimately, to stimulate change. Emma reflects on how tickling has been carried out through tactics like covert distribution of abortion medication, women publicly declaring that they have procured or helped to procure an abortion, and openly providing information on the ways in which feminist activists assist in pushing the boundaries of the criminal law. ${ }^{41}$ This strategy of 'tickling' serves to stage a disruption to law, legal time and its subjects. It challenges law's dominant narrative about itself in acts of resistance. These acts are reminiscent of the actions of others who have acted as provocateurs to law in areas such as welfare, ${ }^{42}$ racial injustice ${ }^{43}$ and decolonisation. ${ }^{44}$

39 On criminality as provocation in struggles for law reform in Ireland, see Máiréad Enright and Emilie Cloatre, 'Transformative illegality: how condoms "became legal” in Ireland, 1990-1993' (2018) 26(3) Feminist Legal Studies 161; Emilie Cloatre and Máiréad Enright, “"On the perimeter of the lawful": enduring illegality in the Irish family planning movement, 1972-1985’ (2017) 44(4) Journal of Law and Society 471.

40 A similar approach is evident among some artistic interventions in abortion law reform in Ireland: Fletcher (n 31).

41 Radhika Sanghani, “Arrest us”: Northern Ireland women want to be prosecuted for breaking abortion laws” The Telegraph (London 26 June 2015) < https://www.telegraph.co.uk/women/womenslife/11700651/Abortion-Northern-Irish-women-want-arrest-over-illegal-abortion-pills.html>.

42 Austin Sarat, “'...The law is all over”: power, resistance and the legal consciousness of the welfare poor' (1990) 1(2) Yale Journal of Law and the Humanities 343.

43 Patricia Ewick and Susan Silbey, 'Conformity, contestation, and resistance: an account of legal consciousness’ (1991) 26(1) New England Law Review 731.

44 Mindie Lazarus-Black and Susan Hirsch (eds), Contested States: Law, Hegemony and Resistance (Routledge 1994). 


\section{Abortion activism, legal change, and taking feminist law work seriously OA19}

\section{The multifaceted nature of feminist law work}

The participants in our workshop and interviews are neither lawyers nor institutional feminists employed by state or government bodies. ${ }^{45}$ However, their perspectives on legal change should not be viewed as 'external'; they have been intimately caught up in legal change. In particular, they are adept at identifying locations of law work and at strategising across various locations - formal and informal, parliamentary and judicial, national and transnational - to build momentum towards formal legal change. In consequence, the locations of feminist law work are multifaceted and overlapping.

Given the long-term lack of movement towards reform via referendum (Ireland) or legislative change (Northern Ireland), feminist activists in both jurisdictions had to find alternative fora and spaces - domestic courts and international human rights bodies, for example - in which to develop and publicise their arguments for change. In other words, when legislatures were unresponsive to demands for a liberalising referendum, ${ }^{46}$ more permissive constitutional interpretations, ${ }^{47}$ or legislative change, ${ }^{48}$ feminist activists mobilised other legal sites for 'politics by other means' ${ }^{49}$ Legal arguments developed at these sites were then translated back into potential legislative discourse once the opportunity emerged, sometimes with a view to compelling parliamentarians to act, or reacting to politicians reneging on commitments to support change. Speaking of her daughter Sarah Ewart's experiences in trying to secure help from politicians after having to travel for termination in a case of fatal foetal anomaly, Jane Christie captured this process and strategy of moving between politics and law:

... we wrote to 108 MLAs ... we ended up trying our best as Sarah said for two years going round the MLAs, we got absolutely ... there was plenty of understanding, plenty of comparisons in their own situations but nobody was actually listening to us. We got agreement from the DUP that they would not use a petition of concern and they would support [a Bill proposing access to abortion in cases of fatal foetal abnormality]. At that stage then they backpedalled with us, they had agreed also a change in law, [a senior politician] back-

45 Holly McCammon and Amanda Brockman, 'Feminist institutional activists: venue shifting, strategic adaptation, and winning the Pregnancy Discrimination Act' (2019) 34(1) Sociological Forum 5.

46 In Ireland the referendum was not confirmed until after both a Citizens' Assembly and a specially convened Oireachtas Committee recommended it; Cabinet did not propose it to the Oireachtas spontaneously. The only substantive referenda on abortion that had been proposed since $1983 \mathrm{had}$, in fact, sought further to restrict access to abortion and to reverse the Supreme Court decision in Attorney General v X [1992] 1 IR 1 that abortion was constitutionally permissible where the pregnant person was at real and substantial risk of suicide. See further Máiréad Enright, 'Abortion law in Ireland: reflecting on reform' in Lynsey Black and Peter Dunne (eds), Law and Gender in Modern Ireland: Critique and Reform (Hart Publishing 2019) 55.

47 In Ireland attempts to pass legislation that would permit abortion in cases where the foetus had been diagnosed with a fatal anomaly and which were arguably permissible given a more liberal constitutional interpretation were unsuccessful, based largely on Attorney General advice that any such legislation would be unconstitutional. This is in spite of the fact that this was far from entirely settled as a matter of constitutional interpretation. See further Jennifer Schweppe and Eimear Spain, 'When is a foetus not an unborn? Fatal foetal abnormalities and Article 40.3.3' (2013) 1 Irish Journal of Legal Studies 92; Aisling McMahon and Bríd Ní Ghráinne, 'Reconsidering the Irish Constitution and international law: abortion and fatal fetal abnormality' (5 March 2018) < https://papers.ssrn.com/sol3/papers.cfm?abstract_id=3134542>.

48 When Ireland finally legislated to give effect to the limited right to access abortion under the 8th Amendment in 2013, the legislation was unduly restrictive and all attempts to amend the proposed legislation so that it was compliant with the Constitution but not punitive failed. See Claire Murray, 'The Protection of Life During Pregnancy Act 2013: suicide, dignity and the Irish discourse on abortion' (2015) 25(6) Social and Legal Studies 667.

49 Richard Abel, Politics by Other Means: Law and the Struggle against Apartheid (after the Law) (Routledge 2002). 
pedalled with us, and at that point Sarah and I realised that to get any help we were going to have to go through the courts.

This comment also gestures towards the first location of multifaceted feminist law work: domestic courts and litigation.

\subsection{DOMESTIC COURTS}

In Northern Ireland domestic litigation was a core element of the strategy for legal mobilisation and law reform. This took a number of forms and particular recent highprofile cases - Ewart's case, ${ }^{50} A$ and $B^{51}$ and the judicial review initiated by the Northern Ireland Human Rights Commission ${ }^{52}$ - were turning points, not only in terms of substantive law but also in terms of connecting legal doctrinal abstraction to empirical lived realities for the electorate. Speaking directly to Sarah Ewart, Kellie O'Dowd captured the importance of her case for the movement quite beyond the strict legal outcome:

... until Sarah, until what happened to you did happen and came out into the public, like, you know, we would have meetings and there'd be two people and a dog turn up, and you're kind of going abortion law reform's never going to happen, we're never going to get the [19]67 Abortion Act extended. But then when your story went public, it absolutely changed the discourse because if you have a situation where it's surrounded by silence and stigma, but you were the human face and you were the wanted, the very much wanted pregnancy and it kind of really opened people's minds to going 'what do you mean she can't access abortion here? What do you mean she has to be basically, she has to go to London to access this?' That made people interested and it made them sit up so I know that youse [referring to Sarah and Jane] didn't know what was happening in terms of what was going on for you, but as an abortion rights activist who had been working on this for five years, it was the light bulb that we had needed in terms of saying this is what happens to women who can't access reproductive healthcare here. So, I want to thank you ... And I always said that ... the tipping point when we're out doing workshops would be the Sarah Ewart case and everybody knows that case and everybody can relate to that and it's so tangible because it allows us to have those conversations.

This seemed in some ways to be precisely what Sarah Ewart hoped would be the effect of her decision to pursue justice through the courts. Even though her mother, Jane Christie, said '[w]e don't class ourselves as activists but we can clearly see that there is a problem here in Northern Ireland ... and it's disgusting', Sarah's motivation was clear. In her words, she decided 'we'll just keep going until we try and get it changed'. This illustrates well the agency and the feminist law work involved for individual litigants in taking cases of this kind: Sarah's case was taken partly for herself, but partly also to redress an injustice that was systemic and that was impacting on other women, and which politicians in Northern Ireland did not seem to be willing to resolve.

Other cases pursued not by those seeking reform, but by the state, also played important roles in turning the tide in Northern Ireland; particularly the case of a woman

50 Ewart (n 6).

$51 \mathrm{R}$ (on the application of $A$ and B) (Appellants) $v$ Secretary of State for Health (Respondent) [2017] UKSC 41.

52 Northern Ireland Human Rights Commission (n 22); In the Matter of an Application by the Northern Ireland Human Rights Commission for Judicial Review (Northern Ireland) [2018] UKSC 27. 


\section{Abortion activism, legal change, and taking feminist law work seriously OA21}

who was prosecuted for acquiring abortion medication for her daughter. ${ }^{53}$ It reinforced - North and South - the potency of continuing criminalisation, and activists were involved in ensuring that, as much as possible, the case proceeded through the courts rather than disappearing quickly through a guilty plea. Goretti Horgan reflected on this case to show how this process illuminated both the inadequacy of the existing law's framing of abortion, and the lived costs of enforcing the law:

That actually makes me think ... [of] the mother who's taken the judicial review on the decision to prosecute her for getting the abortion pills for her daughter, because when that was reported in the media, it was reported that she was charged with getting 'poison' to try to cause her daughter to have an abortion. ${ }^{54}$ Now the poison was those very safe pills and that are available on the NHS, et cetera. And ... everybody else pleaded guilty and accepted a caution or whatever so there was never any, there was never any narrative about them except what we ourselves kind of knew in private or whatever ... And I think that some of what's come out since, I mean the fact that the police actually took the daughter out of her classroom, to be interviewed ... we wouldn't have heard that if the court case hadn't happened. You know, there's a whole lot of like small details like that that have absolutely horrified even people who are against abortion. They're saying why would they do that to a wee girl who's had enough on her plate anyway. People who were forced, there have been too many people who were forced to tell their stories ... You know, people forced to tell their stories who maybe really would want - including you, Sarah, you know, who'd prefer to be private and everything but are forced to tell them because of these awful laws that we have and to go through court cases that really, they shouldn't have to.

Feminist law work moves between locations - courts and legislature, for example because it understands that legal principles formulated at one site may be transformed and transformative when they are translated for another. For instance, a case that has 'failed' in court may produce unexpected victories when it is considered by the legislature. ${ }^{55}$ Goretti Horgan describes an example of the latter in the aftermath of the UK Supreme Court decision in $A$ and $B .{ }^{56}$ The litigants in that case asked for free access to abortion from the National Health Service for women resident in Northern Ireland. While the court ultimately decided against those women, Alliance for Choice's campaigning around this case was instrumental in the government's decision, announced the following day, to facilitate free access for Northern Irish women. That decision had a real and positive effect in making abortion accessible - albeit subject to travel - for many more women in Northern Ireland. Again, that was made possible through a long-term engagement with the question of securing free NHS abortions for people in Northern

53 Alan Erwin, "Prosecution of Northern Ireland mum for buying daughter abortion pills "did not breach human rights," court rules’ Belfast Telegraph (16 December 2019)

$<$ https://www.belfasttelegraph.co.uk/news/northern-ireland/prosecution-of-northern-ireland-mum-forbuying-daughter-abortion-pills-did-not-breach-human-rights-court-rules-38788749.html>.

54 This is a reference to section 58 of the Offences Against the Person Act 1861.

55 Michael McCann and George I Lovell, 'Towards a radical politics of rights' in Paul Christopher Grey (ed), From the Streets to the State: Changing the World by Taking Power (SUNY Press 2010) 139,155; Douglas Nejaime, 'Winning through losing' (2010-11) 26 Iowa Law Review 941.

$56 A$ and $B$ (n 51). For wider discussion, see Leanne Cochrane, 'Devolution and discrimination between citizens under Article 14 ECHR: preserving local provision' (2017) 76(3) Cambridge Law Journal 472; Stephen Cragg, 'Abortion, Northern Ireland and the NHS in England: can respect for devolved governments be a justification for discrimination?' (2017) 4(2) Journal of International and Comparative Law 377. 
Ireland, and through productive engagement between activists and sympathetic practising lawyers. Goretti Horgan describes it thus:

Whenever Alliance for Choice first started, and we were looking to get the Abortion Act [1967] extended to here ... [we were told] it couldn't happen, it would destroy the Peace Process. Literally for ten years we were told that from 1998 to 2008 ... How, I don't know. So, then when we realised that wasn't going to happen, we started to look for free abortions on the NHS and I think like it was about 2002 we thought about taking a legal route and we started looking, we actually put out a press release and it was covered in the papers and all, looking for somebody who would be willing to try to get an NHS abortion and then take a case about it ... and we were getting questions asked in Parliament all the time ... we had lawyers in London ... kind of older people, like my age, and they were keeping an eye the whole time and in 2012 they came and said, you know, you don't have to have somebody who's asked, we've checked, you don't have to have somebody who's asked for an NHS abortion, you just have to have somebody who's got like a good story and we'll take, you know, we will run. So, that's how the $A$ and $B$ case $^{57}$ came about. Now, we never thought that that would work and sure enough it didn't because actually they lost, they lost in the Supreme Court and yet the very next day, the announcement was made that there would be free NHS abortions ... And certainly without the court case, it probably wouldn't have been even in their minds, so like ... it didn't win, but it helped.

In this respect, activists in Northern Ireland had perhaps a greater appreciation of the potential of court cases than some lawyers involved and worked to ensure that cases went ahead. Of one such case, Goretti Horgan remembered:

And the fact that she then, that her lawyers, I mean, there was ... there was a lot of activist intervention that led to her lawyers realising that there were defences that she could put forward and that it wasn't a case that, you know, she just had to do what everybody else did and plead guilty in order to get it over with. I think that if it hadn't been for the activists' interventions with her barristers etc, that that actually, you know, she may not be taking that case now and of course we crowdfunded to make sure that she was able to get started on the judicial review because there was a big nervousness about it and she ... was very frightened about being left with costs and things like that ... So ... there was activist involvement in ensuring that the case did actually happen.

\subsection{INTERNATIONAL HUMAN RIGHTS LAW}

As well as domestic litigation, international human rights law emerged as indispensable to the process for change in Northern Ireland and a key location for feminist law work. However, leveraging that body of law required significant legal sophistication, given the constitutional complexities of the devolution settlement. Prior to the devolution of criminal justice powers to Stormont in 2010, activists in Northern Ireland focused their campaigning efforts on Westminster. Following 2010, attention turned to Stormont and lobbying for devolved action. When it became clear that this approach would not be fruitful, activists reframed abortion as a matter of international human rights law compliance, arguing that there was no constitutional impediment to Westminster intervention.

This required a number of critical steps. The first was establishing that the law in Northern Ireland violated human rights and, particularly, the Human Rights Act 1998. 


\section{Abortion activism, legal change, and taking feminist law work seriously OA23}

This was achieved through domestic litigation. ${ }^{58}$ Sarah Ewart was an intervener in this case. The second was establishing that, as a matter of human rights law, Westminster could be compelled to attend to abortion in Northern Ireland notwithstanding the devolution settlement. This was achieved largely by lobbying MPs and engaging in various parliamentary processes, including the Women and Equalities Committee consultation on abortion in Northern Ireland. ${ }^{59}$ Alliance for Choice was central to coordinating and shaping this work. The third was establishing that the law as it stood constituted violations of international human rights law, which was achieved when Alliance for Choice and other organisations ${ }^{60}$ successfully requested an inquiry from the CEDAW Committee. ${ }^{61}$ In the course of the inquiry, when Committee members visited Northern Ireland, it was found that the law produced manifest violations of international human rights law. ${ }^{62}$ This inquiry advanced the (successful) argument that Westminster was not precluded from taking action on abortion and, in fact, that the UK had an international obligation effectively to take steps to resolve those violations of human rights law. The fourth was creating clear imperatives for and guidance in respect of what could be done to resolve these violations at a doctrinal level, including putting an end to ongoing and active prosecution for people participating in (unlawful) self-managed abortion in Northern Ireland. Again, this was significantly achieved by engagement with the CEDAW Committee, which expressly recommended a moratorium on future prosecutions and the cessation of ongoing prosecutions. ${ }^{63}$

As a result of this ability to shift between courts and institutions, from the national to the transnational and back again, activists in Northern Ireland successfully and strategically deployed international human rights law in laying the groundwork for the decriminalisation of abortion in October 2019 and its subsequent regulation. As this suggests, feminist law work requires shifting between - and sometimes working across different national and international locations simultaneously. Even if activists are focusing on a law-making process outside of parliament, they must also work to ensure that the outcome of that process will be well received by the legislature in future and seek support from international bodies when debate at the national level has become stymied.

In the Republic of Ireland, the dominant and very limiting mainstream interpretations of the 8th Amendment meant there was little opportunity to force the Oireachtas to liberalise abortion law using domestic litigation. ${ }^{64}$ Instead, arguments were made in international judicial and quasi-judicial institutions. In particular, although litigation in

58 Northern Ireland Human Rights Commission (n 22). In this case violation of Article 8 was held obiter following a finding that the Commission lacked standing: Jane Rooney, 'Standing and the Northern Ireland Human Rights Commission' (2019) 82(3) Modern Law Review 535; Bríd Ní Ghráinne and Aisling McMahon, 'Abortion in Northern Ireland and the European Convention on Human Rights: reflections from the UK Supreme Court' (2019) 68(2) International and Comparative Law Quarterly 477.

59 Women and Equalities Committee, Abortion Law in Northern Ireland: 8th Report of Session 2017-19 (HC 1584, 2019).

60 The Family Planning Association for Northern Ireland and the Northern Ireland Women's European Platform.

61 Catherine O'Rourke, 'Advocating abortion rights in Northern Ireland: local and global tensions' (2016) 25(6) Social and Legal Studies 716.

62 CEDAW Committee (n 25).

63 Ibid.

64 For analysis see, for example, Fiona de Londras, 'Constitutionalizing fetal rights: a salutary tale from Ireland' (2015) 22(2) Michigan Journal of Gender and the Law 243. 
$A, B \& C v$ Ireland ${ }^{65}$ did not demonstrate that the 8 th Amendment violated the European Convention on Human Rights, it did identify that the absence of any process by which women could assess whether they were entitled to access abortion within the limited constitutional provision constituted a violation of Article 8. As a result, the Oireachtas legislated for access to abortion in 2013 - a full 30 years after the constitutional provision was introduced. While the $A, B \& C$ litigation failed in its broader objective to establish the rights-incompatibility of the constitutional status quo, it made clear the limitations of the constitutional framework and coincided with the death of Savita Halapannavar, a woman who died following refusal of abortion in Galway in 2012, and whose death ignited widespread activism, bolstering the preceding practices of pro-choice feminist activists. ${ }^{66}$ As Ailbhe Smyth put it, 'the case that really did make a difference to our more recent campaigning was the $A, B, C$ : the set of three cases that went to the European courts and the European courts gave an instruction to government that they had to clarify the legislative parameters'. ${ }^{67}$

The experience of engaging with the European Court of Human Rights and seeking clear determination that Ireland's law violated human rights nudged activists towards other international institutions, specifically the United Nations (UN). The UN Human Rights Committee found - in Mellet $t^{68}$ and Whelan $^{69}$ - that the prohibition of abortion in situations of fatal foetal anomalies could constitute a violation of the right to be free from torture, inhuman and degrading treatment or punishment protected in the International Covenant on Civil and Political Rights, further bolstering the arguments for change. While these engagements with international human rights law were useful in the campaign for repeal of the 8th Amendment in Ireland, they were not per se critical to securing the commitments to the Citizens' Assembly and then to the referendum of 2018. Those commitments are better understood as the product of a combination of political coincidence, timing, and relentless and resilient feminist activism.

This engagement with national and international spaces demonstrates our previous comment above that law reform processes are not linear. Recognising often-unexpected spaces, moments and events as landmarks and opportunities to articulate and make claims for reproductive justice and abortion law reform was a critical part of feminist law work, both North and South. Activists had to be ready when the tide turned. National and international challenges surrounding Brexit also offered another opportunity for activists in Northern Ireland. For example, Kellie O'Dowd noted how the minority government in Westminster, reliance on the DUP, Brexit, and resulting tensions between the DUP and other Members of Parliament created opportunities that Alliance for Choice was ready to take advantage of. Indeed, that preparedness to take advantage of such situations was part of their activist strategising:

65 A, B and C v Ireland Application No 25579/05, Merits, 16 December 2010. For discussion, see Katherine Side, 'A B and C versus Ireland: a new beginning to access legal abortion in the Republic of Ireland?' (2011) 13(3) International Feminist Journal of Politics 390.

66 Máiréad Enright and Fiona de Londras, "Empty without and empty within": the unworkability of the Eighth Amendment after Savita Halappanavar and Miss Y' (2014) 20(2) Medico-Legal Journal of Ireland 85.

67 The Protection of Life During Pregnancy Act 2013 followed soon after this case and the death of Savita Halappanavar.

68 Mellet v Ireland (2016) UN Doc CCPR/C/116/D/2324/2013. For discussion, see de Londras (n 7).

69 Whelan v Ireland (2017) UN Doc CCPR/C/119/D/2425/2014. For discussion, see Katarzyna SękowskaKozłowska, 'A tough job: recognizing access to abortion as a matter of equality. A commentary on the views of the UN Human Rights Committee in the cases of Mellet v Ireland and Whelan v Ireland (2018) 26(45) Reproductive Health Matters 25. 


\section{Abortion activism, legal change, and taking feminist law work seriously OA25}

I suppose $\ldots$ in any crisis you have to take the opportunities that present themselves ... the shit show that is Brexit - excuse my language - and the Tory reliance on the DUP has played into our hands because we've had Labour and Conservative MPs who ... want to give the DUP a bloody nose ... in this area of chaos, we've been able to, I suppose, gain some political capital. And we're going to keep on doing that.

Or as Emma Campbell put it:

... to misappropriate another famous Irish phrase, England's misfortune is Northern Ireland's opportunity at the minute and we're trying to make sure that we're not going to leave them alone about abortion in Northern Ireland and we really hope that it causes them a massive pain in their side.

This key demand of feminist law work - to be active at many sites at once and to 'get our fingers in all the abortion pies' (Emma Campbell) - played out differently on each side of the Irish border. Given Northern Ireland's place within the post-colonial, and soon-to-be post-Brexit, UK, Northern Ireland activists worked not only in varied locations of legislatures, courts and international processes, but also in various jurisdictions. They undertook feminist law work in Northern Ireland, in Westminster, and in the Republic of Ireland where they substantially supported efforts for Repeal, both as a marker of the allisland nature of abortion rights activism and because success in the South held significant potential for momentum in the North.

\subsection{LEGAL EDUCATION IN THE PUBLIC SPHERE}

The wider public sphere is also, of course, a site of activist legal mobilisation. As McCann has written of social movement litigation, legal activism has 'radiating' or 'spillover' effects and value beyond the formal legal process and its instrumental gains and losses, through moments of engagement with legal institutions and opportunities increasing public rights consciousness, for instance. ${ }^{70}$ Much feminist law work goes into translating ${ }^{71}$ or 'vernacularising'72 new legal claims and norms wrung from legal processes for everyday usage and understanding. ${ }^{73}$ This activity was evident in the abortion rights campaigning on the island of Ireland as well. Erin D'Arcy describes in detail how she used 'In Her Shoes' to translate legal concepts for ordinary members of the public engaging with her website:

Maybe a year ago or so I probably wouldn't have been able to pronounce [the word] autonomy or know what it meant. So, I had to look it up and go, 'What does autonomy even mean? I've heard this word, I've seen it, I don't even know how to say it'. And I feel like a lot of people have no idea and so these words are all being used by professionals and people who are, you know, knowledgeable or whatever and it really alienates a lot of people and so they feel like, 'I don't know what this is, I don't know how to say it'. And so when I realised that myself ... I kind of tried to help break that down a little bit ... So like I would use the word autonomy and then I would also include 'the right to govern myself' in the explanation. So that way people who are reading ... would start to piece that together

70 McCann (n 35).

71 Ruth Fletcher '\#RepealedThe8th: translating travesty, global conversation, and the Irish abortion referendum' (2018) 26 Feminist Legal Studies 233.

72 Sally Engle Merry, Human Rights and Gender Violence: Translating International Law into Local Justice (University of Chicago Press 2006).

73 For wider work on this point, see Marie-Lise Drapeau-Bisson, 'Beyond Green and Orange: Alliance for Choice-Derry's mobilisation for the decriminalisation of abortion' (2020) 35(1) Irish Political Studies 90. 
Emma Campbell also described an important part of Alliance for Choice's current strategy as being focused on 'educating people mostly in England about what Northern Ireland is and the fact that we don't have an abortion law.'

Accordingly, activists are simultaneously law-makers and strategic teachers of law. They not only help the public to understand what law is but also make them aware of opportunities to engage in the democratic process around law and law reform. The activist role in translating the outcomes of formal legal processes for a wider political audience is crucial to legal change. However, legal discourse is not necessarily 'made' at one site and 'translated' at another; feminist law work means active intervention in both spaces and is directly generative of new legal norms. Activist legal agency is not confined to reacting to missives from 'a distant, official terrain wholly defined by elite judges, lawyers and professional legal commentators'. ${ }^{74}$ As this account of feminist law work shows, that terrain is neither distant nor necessarily official, and is formed by and through imaginative and insistent activist interventions.

\section{The 'everydayness' of feminist law work}

Having pieced together a view of the multiple spaces and complex approach to law in feminist law work, it is necessary to turn to the everyday nature of this work. What are the everyday practices and activities that stimulate legal change? The discussions emerging from our interviews and workshop indicate that there are a number of responses to this question. We will focus on three: adaptability and skill; narrative production and management; and labour.

\subsection{ADAPTABILITY AND DEVELOPING NEW SKILLS}

First of all, and perhaps definitively, feminist law work requires feminist activists to be adaptable. Such work often demands the development of new skills or knowledge to respond to shifting constitutional, legal, political or social opportunities and developments. ${ }^{75}$ This is particularly evident in the context of Northern Ireland. Following the collapse of the devolved Assembly at Stormont in January 2017 the jurisdiction did not have a functioning devolved government until January 2020. This meant that there was not a working legislative institution in Northern Ireland through which formal law reform could be advanced. There was also a clear acceptance that, even if it were functioning, Stormont was a hostile place for abortion law reform. As Kellie O'Dowd explained in a pre-workshop interview:

We have fucking research after research, we have just a legislature that are not fucking interested, so we need to take this opportunity ... [] f they legislated, if they were pushed, through public opinion, to legislate it would be FFA [fatal foetal anomaly] and maybe sex crimes, they might even wiggle out of that, and it would be tiny legislative change, so the hope is that we get this sorted out before they get back. ${ }^{76}$

74 Michael McCann and George I Lovell, 'Towards a radical politics of rights' in Paul Christopher Grey (ed), From the Streets to the State: Changing the World by Taking Power (SUNY Press 2010) 139, 141. See also Michael McCann, 'Reform litigation on trial' (1992) 17(4) Law and Social Inquiry 715, 731

75 Emma Campbell, 'From grassroots to government: arts engagement strategies in abortion access activism in Ireland' in Colleen MacQuarrie, Fiona Bloomer and Claire Pierson (eds), Crossing Troubled Waters: Abortion in Ireland, Northern Ireland, and Prince Edward Island (Island Studies Press 2018).

76 Goretti Horgan, by contrast, wondered whether, if abortion was decriminalised by Westminster, Stormont would be capable of legislating on abortion at all. 


\section{Abortion activism, legal change, and taking feminist law work seriously OA27}

As a result - as noted above - feminist groups turned their focus to Westminster, to primary legislation, and to issues of constitutional law and devolution, all in the context of ongoing negotiations regarding the UK's planned exit from the EU. In navigating this shift, feminist activists not only had to develop a host of new arguments (about devolution, for example, and the question of whether abortion is a reserved or devolved issue), but also adapt to new political challenges in a context where the predominant sentiment in the Westminster Parliament is at least somewhat pro-choice. Emma Campbell reflected on what this has required of activists:

There's a slight issue with the Northern Ireland campaigning at the minute having to be at Westminster ... we are not convincing MPs in Westminster to be pro-choice. The house is pro-choice. We are talking about issues of devolution, we're talking about the Sewell Convention ... I've read the Good Friday Agreement for no thanks whatsoever.

In this respect, activists are required to respond to political and legal changes, look to different areas of law, and expand their networks and resources in these areas. They must do so often in very short time-frames, needing to be ready to offer quick, digestible analysis, proposals, expertise, and arguments to a range of audiences, even in highly technical and sometimes unclear or uncertain terrains of law.

This adaptability means that we can understand legal claims-making not only as a tool which facilitates campaigning but also as a resource that shapes and changes social movements. ${ }^{77}$ As activists have become experienced in law reform processes - albeit approaching law often rather instrumentally - they have invested greater resources and energies in legal mobilisation, leading to shifts in future tactics and in their selfunderstanding as legal actors. The challenge that this poses is exacerbated when we consider that, like many feminist activists, they must adapt, not only to single mode of feminist law work (formal legal change) but also between modes of work. In particular, they must adapt relationships between policy and law reform work and direct assistancebased activism for abortion-seekers. ${ }^{78}$ In addition to being lay-lawyers and legal commentators, our participants are also involved in activity to support abortion-seeking women, to help them practically, to offer counselling, to engage in training and awarenessraising campaigns, to engage with the media on a regular basis, and to construct a voice on social media. These are disparate forms of activity requiring differing skills, a degree of self-training and an ability to switch between these positions on a daily, weekly or hourly basis. As Susan Buck-Morss has observed, when activists teach and train themselves, they also empower themselves for future action. ${ }^{79}$ In time, Alliance for Choice found that political and legal allies came to rely on them so that being able to fulfil that role becomes central to their ability to influence the legal process. As Kellie O'Dowd says:

In the morning if [abortion was decriminalised] and there had to be a submission on well what do you want the new law to look like, I have no doubt that politicians would call me. You know I have no doubt about that. Because they haven't a fucking clue and they know we're the real experts.

77 Colm Campbell and Ita Connolly, 'A deadly complexity: law, social movements and political violence' (2007) 16 Minnesota Journal of International Law 265.

78 Judith Orr, Abortion Wars: The Fight for Reproductive Rights (Policy Press 2017) 25-27.

79 Susan Buck-Morss, 'Democracy: an unfinished project' (2014) Boundary 92. 


\subsection{NARRATIVE PRODUCTION AND MANAGEMENT}

Notably, feminist activists are involved in narrative production, and management of these narratives. ${ }^{80}$ Social movements literature emphasises the role of activists in 'framing' social problems in ways that convince sympathetic members of the public of the need for collective action. ${ }^{81} \mathrm{~A}$ frame is a simplified, condensed reinterpretation of a social problem. It often reworks older, culturally embedded interpretations, amplifying some aspects and extending others. Perhaps one of the most important elements involved in feminist law work on abortion, then, is the framing, production, curation and advancement of narratives from and about women's, and others', experience of current legal and healthcare frameworks regulating abortion. ${ }^{82}$ These narrative accounts have proven powerful and affective in both jurisdictions as a way to educate about abortion and to stimulate public discussion; they make concrete the real life of abortion law and can underpin significant shifts in public opinion (held and/or expressed). This is evident, for example, in the public mobilisation and shifts in political discourse that occurred following Savita Halappanavar's death in Galway in 2012 and Sarah Ewart's decision to speak of her experience of being denied abortion care in Northern Ireland in 2013. For our participants, such narratives were a way of making law real and affective, showing its impacts and calling for accountability. They recognised the power of this narrative production, as well as its costs for those whose lives and experiences were publicised, as made clear in the exchange between Kellie O'Dowd and Sarah Ewart already recounted above.

These narratives emerge as a means through which feminists can seek to 'hack' the legal system. By this we mean that they can stimulate a change in debate when other sources, including law, cannot; such narratives can be employed to break deadlock or stagnation in discussion on abortion law and its everyday effects. In particular, as Francesca Polletta has argued, narratives rely on 'emotional identification or familiar plots rather than on testing or adjudication of truth claims'. ${ }^{83}$ Stories of personal experience are difficult for opponents to negate. In addition, they give abstract legal frames a plot and map them onto a set of lived experiences. ${ }^{84}$ For this reason, narratives can connect people to claims for justice in the way that 'simple' legal or political arguments might not; as Kellie O'Dowd said:

$[\mathrm{H}]$ uman rights doesn't work. Bodily autonomy doesn't work. Feminist arguments don't work. Your story, real life stories, do absolutely work.

80 Lisa Hallgarten, 'Abortion narratives: moving from statistics to stories’ (2018) 391(10134) Lancet (2018) 1988.

81 David Snow and Robert Benford, 'Master frames and cycles of protest' in Aldon Morris and Carol McClurg Mueller (eds), Frontiers in Social Movement Theory (Yale University Press 1992); Dawn McCaffrey and Jennifer Keys, 'Competitive framing processes in the abortion debate: polarization-vilification, frame saving, and fame debunking' (2000) 41(1) Sociological Quarterly 41; Judith Butler, Frames of War: When is Life Grievable? (Verso 2016).

82 These often compete with other frames, such as those produced by the media: Orla McDonnell and Padraig Murphy, 'Mediating abortion politics in Ireland: media framing of the death of Savita Halappanavar' (2019) 16(1) Critical Discourse Studies 1.

83 Francesca Polletta, “It was like a fever ..." narrative and identity in social protest' (1998) 45(2) Social Problems 137.

84 Kristine Olsen, 'Telling our stories: narrative and framing in the movement for same-sex marriage' (2014) 13 Social Movement Studies 248. 


\section{Abortion activism, legal change, and taking feminist law work seriously OA29}

At the same time, personal narratives afford a subject position to those telling their stories that formal legal process has not offered. ${ }^{85}$ As Sarah Ewart explained:

Yeah, in court you're very much just a case. You're not really a person. I find when like when we met with [a conservative public figure], she said 'oh I read your stuff in the papers'. But when she came to the house and actually heard what all had happened, she was like 'I didn't realise'. But she sat in tears at different parts of me telling her things. So, I think telling it like this and meeting with people is completely different to how it's come through court ...

An important part of feminist law work in this area, therefore, is framing these stories and making decisions on how they can best be used, while maintaining respect for the position of the woman who speaks. This was a prominent theme in Erin D'Arcy's account of managing 'In Her Shoes'. Erin reflected on her role as one of careful, political curation:

I didn't have like rules to follow of what stories I could tell and what stories I should not tell but I knew that there was a responsibility in what stories were going out and the amount of people that were reading them and how it would impact their vote ... there were some stories that ... I knew wouldn't be received well given what had been going on in the media at the time and so I ... had to hold it until maybe after the referendum or a different day, depending on what was going on.

Through its effective production of narrative, 'In Her Shoes' offered people a way to have difficult conversations, on and offline, and had the potential to appeal to a wide variety of people who were often outside the traditional remit of feminist activism. Speaking of the website, Linda Kavanagh said:

$\ldots$ it was so, so important and for women to be able to tell their stories anonymously and then for people to be able to share it in a way that was nonconfrontational was really, really powerful, and it really, really worked.

However, narrative production is also a weighty and a challenging part of feminist law work. Our participants demonstrated keen awareness of the ethical concerns that come with narrative production and management. These include the privacy of the individuals involved, including some caught up with law, who perhaps did not want to have their stories told in such a public way. Feminist law work's commitment to women's agency, autonomy and lived experience creates ethical compulsion towards taking care in the production of these narratives. Erin D'Arcy's story of the daily labour involved in curation of 'In Her Shoes' illustrates this in clear terms. By the end of the referendum campaign, 10-15 people a day were sending their abortion stories to her:

I kind of felt a lot of personal responsibility that when they were sending me these stories that I needed to be there because I was very, very aware that people were anxious to send something like that, and also that they were really vulnerable sending that. A lot of times women would tell me that it was their first time ever telling somebody or their first time every writing it down and how healing that was for them. So, I did feel a lot of responsibility to make sure that I was there. And being there also meant that I had to monitor all the comments coming in so ... I kind of had to be actively there on my phone 24-7 really, which meant that at 2 o'clock in the morning when I woke up to nurse my baby, that I'm going through my phone to check the notifications to check comments and

85 On feminist critiques of courtroom processes as objectifying, see e.g. Sara Cobb, 'Transcribing the body and materializing the subject' in Michael Hupek and Gary P Radford (eds), Transgressing Discourses (SUNY Press 1997) 195. 
make sure that they're okay and to make sure that the page is okay and nothing's been attacked, it hasn't been - nothing you know happened to it. Because [until I drafted some friends in to help me] it was just me doing it and I really didn't want any person who shared their story to wake up in the morning and see horrible comments. I wanted to protect them from that because ... they shared so vulnerably and beautifully with me. So yeah, I lived on my phone constantly.

Despite the work done to care for those who speak, there is, of course a feminist dilemma here, not only for the use of stories that people never intended to tell, but also in the idea that narratives and stories must be retold as a condition of women being listened to. In this process there is a risk that women become exploited, commodified and sacrificed. Erin D'Arcy was aware of this:

[W] shouldn't have to use their stories only to be able to get a law for ourselves ... I don't know if law-makers are understanding that, that we shouldn't have to have Savita [Halappanavar's] name and her face on something for her to be able to get the care she needs. We shouldn't even know her name.

Negotiating effectively with law-making institutions involves certain compromises. ${ }^{86}$ As Reva Siegel has argued, ${ }^{87}$ in order to influence legal change social movements may be required to conform to the 'public value condition', framing their demands in a discourse that resonates with notionally shared cultural norms. This is a political move, which is inevitably shaped by dominant power relations in society. ${ }^{88}$ In their narrative production work activists may also internalise, or at least bargain with, some of the bureaucratic or procedural constraints of legal institutions or media, ${ }^{89}$ with important consequences for advocacy. As Ailbhe Smyth commented:

[O]bviously there is a selection process and that in itself also raises ethical questions. Of course it does. Because you are either explicitly or implicitly thinking about stories which will actually carry the kind of impact and weight and meaning and emotion and message that you want them to carry.

Curating narratives in this way has important disadvantages; as Davina Cooper notes, it may silence non-hegemonic voices and risk conflict and division which will require labour to avoid or repair. ${ }^{90}$ The risks and problematic practices involved must be weighed up by the feminist activist alongside the desire to maintain a feminist perspective and voice in public debate, especially in the media. As Ailbhe Smyth says of the media, 'if you don't give them something, they will go and get it somewhere else'. These are difficult judgements in feminist law work, and these appear as a central part of managing narrative as an important but risk-infused tool.

86 Alba Ruibal, 'Social movements and constitutional politics in Latin America: reconfiguring alliances, framings and legal opportunities in the judicialisation of abortion rights in Brazil' (2015) 10(4) Journal of the Academy of Social Sciences 375.

87 Reva Siegel, 'The jurisgenerative role of social movements in United States constitutional law' $<$ https://law.yale.edu/sites/default/files/documents/pdf/Faculty/Siegel_Jurisgenerative_Role_of_Social_ Movements.pdf $>$.

88 Myra Marx Ferree, 'Resonance and radicalism: feminist framing in the abortion debates of the United States and Germany' (2003) 109(2) American Journal of Sociology 304.

89 Anne Revillard, 'Social movements and the politics of bureaucratic rights enforcement: insights from the allocation of disability rights in France'(2017) 42(2) Law and Social Inquiry 450.

90 Davina Cooper, 'An engaged state: sexuality, governance, and the potential for change' (1993) 20(3) Journal of Law and Society 257. 


\section{Abortion activism, legal change, and taking feminist law work seriously OA31}

\subsection{LABOUR}

Feminist law work, of course, involves labour, little of which is remunerated. Persistence and a commitment to long-term activity towards change at individual and collective levels are essential for feminist activists. ${ }^{91}$ Sometimes the labour that is undertaken is a slow chipping away over time. In the Northern Irish context Sarah Ewart's comments demonstrate an awareness of and a commitment to this kind of persistence: 'we'll just keep going until we try and get it changed. Five years later.' At other times, however, labour is not so demanding in terms of its duration but, rather, in its intensity. This was particularly evident from those involved in the referendum campaign in Ireland. Linda Kavanagh reflects on how this period stimulated a disorientating feeling for activists in hindsight:

[] t's really obviously very nice to be on the other side of that ... it wasn't that

long ago although time has no meaning for me anymore and it feels like decades.

The labour involved in feminist law work, furthermore, must be understood as evolving over time. This evolution must be carefully reflected on and responded to strategically. For example, at the time of our workshop the challenge for those in Ireland was no longer about mobilising support and canvassing for votes, but about motivating supporters to continue in work to secure satisfactory legislative and healthcare frameworks for abortion access on the ground. This required a shift in focus not only for leaders, but for all in the movement, and there are attendant risks of premature demobilisation. As Linda says, this kind of work is 'not as sexy as getting out on the street. It's hard to keep people motivated.'

Throughout our discussions, the emotional toll of this labour, and the demands made on activists by its various forms and shifts were clear. This is not just physical labour, although that is of course involved too, but emotional labour. 92 The idea of "feminist law work' has the potential to bring into view the emotional life of doing and engaging with law as non-lawyers, ${ }^{93}$ a life that is often rendered invisible when we approach law and its reform through more traditional lenses. Both Goretti Horgan and Linda Kavanagh recalled incidents where they were moved to tears by the emotional toll of the unpredictable reform effort - a sudden victory or loss - or the stories of women which they were confronted with which stimulated an affective and empathetic response. Linda Kavanagh describes her experience:

I was crying, you know, at my desk because another story had broken, like Miss Y had broken or the woman in the coma ${ }^{94}$ and ... feeling like it was never going anywhere.

Activists also expressed a variety of other emotions attached to their labour, including dissatisfaction and frustration. As Emma Campbell says of Alliance for Choice, 'we're just used to always being dissatisfied'. This distinct emotional experience can set activists apart

91 Cynthia Enloe, The Big Push: Exposing and Challenging the Persistence of Patriarchy (University of California Press 2017).

92 Jeff Goodwin, James Jasper and Francesca Poletta (eds), Passionate Politics: Emotions and Social Movements (University of Chicago Press 2001); Gavin Brown and Jenny Pickerill, 'Space for emotion in the spaces of activism' (2009) 2(1) Emotion, Space and Society 24; Suzanna Franzway, 'Women working in a greedy institution: commitment and emotional labour in the union movement' (2000) 7(4) Gender, Work and Organization 258.

93 For discussion on emotional labour of actors working within law and legal institutions, see John Hagan and Fiona Kay, 'The emotional toll and exhilaration of human rights activism: gender and legal work at the Hague International Criminal Tribunal' (2011) 37(1) Queen's Law Journal 257.

94 PP v HSE [2014] IEHC 622. 
from their wider families and communities. Linda Kavanagh remembered an illustrative incident in the period after the Repeal referendum victory:

Actually, funnily enough, I was at a funeral a while ago and somebody said ... we ended up talking about the referendum and somebody was kind of asking what I was doing now. And I was like, I'm taking it a bit easy, it took a lot of out me. And they're like, 'Yeah, 64\% [the total Yes vote in the referendum] must be really, really difficult to deal with'. Like really sarcastically. And I was just like, oh, you don't get it. At all. So, the layperson, that is how they will perceive it. They will perceive it as it was nice. It was tough but it was nice in the end, so we're all fine.

For those who have been personally affected by the law, there is a particular emotion involved in their labour which must be recognised. Jane Christie explains the difference simply: 'We're living it. And I think that impacts more.'

While our participants clearly evidenced the demanding and emotional nature of their labour, they also spoke of what sustains them in this work. Often the work is enabled by the relational bonds of their movements, ${ }^{95}$ and the small moments of progress that they can detect. Again, Linda Kavanagh captured this:

I suppose the thing possibly that keeps you doing is your community, you know, the other activists, and then sometimes it's really weird, the small things ... you kind of sometimes take your victories where you can ... you kind of have to take them where you can, because it can seem so long and it can be so dark ... you don't get a lot of May 26ths.

\section{Conclusion}

In this account we have drawn attention to and named feminist legal work as an important form of activity at the heart of legal change processes; one that is often under-considered or rendered invisible by dominant reform narratives. Feminist activists are an often overlooked or invisible part of the plural, non-linear and contingent journeys towards abortion law reform in both Ireland and Northern Ireland. They are not the whole story of reform, but their work is an important part of it. In drawing attention to these nonlegal actors, we have not sought conclusively to define, delineate or deconstruct feminist law work, but to offer a sense - from our engagement with eight activists - of the variety, challenges, skills and indispensability of feminist law work to formal processes of abortion law reform in Ireland and Northern Ireland. Thinking about this manifold, instrumental, creative, emotional and laborious activity as work which is equally important as that undertaken by legislators, lawmakers, judges, and other legal arbitrators offers an additional thread to reflections on the Northern/Irish journeys towards legal change in this area.

More than just a way of making sense of how commitments to change the law were achieved, drawing attention to this work and naming it also holds potential to assist us in understanding the current legal landscape and ongoing activity on abortion law in both jurisdictions. The feminist law work continues even as formal law reform is achieved: it is an ongoing part of shaping new legislation, of publicising legal failure, of highlighting the gaps between law and practice, of insisting on a richer conception of reproductive justice, and in subverting, playing at the edges of, 'being cheeky'96 towards, and 'tickling' (Emma Campbell) law.

95 Mario Diani and Doug McAdam (eds), Social Movements and Networks: Relational Approaches to Collective Action (Oxford University Press 2003).

96 Fletcher (n 20). 


\section{Abortion activism, legal change, and taking feminist law work seriously OA33}

For us as feminist legal scholars, the activists who undertake this work are a vital reminder that it is possible, and necessary, to reimagine law and what is involved in formal legal change processes. They encourage us to consider again (and again) how we understand the limits and excesses of law and the forms of legal knowledge and skills that we value, and to insist on inclusive understandings of what it means to engage with and 'do' law in everyday life. 